Boyko Margarita, Doctor of Sciences (Economics), Professor, Kyiv National University of Trade and Economics,

Kyiv, Ukraine

ORCID: 0000-0003-0249-1432

ResearcherID: N-3073-2016

Bosovska Myroslava,

Doctor of Sciences (Economics), Professor, Kyiv National University of Trade and Economics,

Kyiv, Ukraine

ORCID: 0000-0002-6021-5228

ResearcherID: N-4652-2016

Vedmid Nadiia,

Doctor of Sciences (Economics), Professor, Kyiv National University of Trade and Economics,

Kyiv Ukraine

ORCID: 0000-0002-5010-6394

ResearcherID: N-2889-2016

\title{
GLOBAL IMPERATIVES FORMATION OF TOURIST DESTINATION BRAND
}

The article discusses economic prerequisites for the formation of a brand of tourist direction, which depend on the socio-economic, cultural and political influence of the territory, investment attractiveness, foreign trade and development of exportoriented tourism model are presented. The authors elaborates on the core elements globalization, as a major trend in the process of transformation of social development, has led not only to a global mega environment, but also to high competition for profitable markets, resources, investors and skilled labor. The authors substantiate a scientific position on understanding the territory as a multi-purpose product that has many advantages for market agents. A formal perception of the usefulness of the territory for various agents is also presented. The article presents and analyzes the factors of the formation of a brand of a tourist destination.

Keywords: brand, territory multiplicity, tourist destination, tourist attraction, global imperatives

Бойко Маргарита, Босовська Мирослава, Ведмідь Надія. Глобальні імперативи формування бренду туристичної дестинації.

У статті розглядаються економічні передумови формування бренду туристичної дестинації, які залежать від соиіально-економічного, культурного 
та політичного розвитку території, інвестиційної привабливості, зовнішньої торгівлі та розвитку експортно-орієнтованої моделі туризму. Автори детально описують основні елементи глобалізації, як основну тенденцію трансформації соиіального розвитку, що призвело не тільки до формування глобального мегасередовища, але і до високої конкурениії за вигідні ринки, ресурси, інвесторів та кваліфіковану робочу силу. Обтрунтовано наукову позицію щодо розуміння території (дестинаиіï) як багатоиільового продукту, щзо має багато переваг для ринкових агентів (суб'єктів туристичного бізнесу). Також представлено формальне сприйняття корисності території для різних ринкових агентів. Представлені та проаналізовані фактори формування бренду туристичної дестинації.

Ключові слова: бренд, бренд території, бренд туристичної дестинації, туристична дестинація туристична атракція, глобальні імперативи

Formulation of the problem. The desire of the peoples to establish links among themselves marked the beginning of integration. Motives for integration have become people's desires, such as: the desire to expand their horizons, curiosity or the expansion of new lands and various resources. Globalization, which is mirrored by the escalating mobility of capital, people, ideas and information on a universal scale, has become a sweeping theme in the contemporary world (ZHAO Weibing, LI Xingqun, 2007). We share the scientific position of A. McGrew (1992), who argues that globalization is the multitude of relationships and interactions between countries and societies that make up the current global system. Tourism is a global system, accordingly, the analysis of global imperatives that affect the attractiveness of a territory is an actual research.

Over time, was appeared the world economy and various political, cultural, social ties between the peoples in all over the world. In the modern world, every day there are various business processes that characterize the work of the world market. These processes are affected by a number of factors that should be monitored and controlled by enterprise employees for the successful operation of the company on the market. Therefore, there is a position that, the most important phases of destination branding processes are based to define and communicate to the tourists the main brand value driver of place (M. Risitano, 2005).

Globalization is typified by the rapid movement of people, information and capital across national borders worldwide in ways that would have been difficult to envision not too many years ago.

The advances made in transportation that have enabled global mobility are particularly significant. Modern aircraft, cruise ships, trains, and other modes of transport allow people to move quickly and relatively cheaply. Fast trains, road systems, and even city bike rental programs enable people to move, tour, and explore the world. These changes have allowed more people to travel more often in less time. 
Travel and Tourism has been outpacing the global economy for the past six years, which is reflected in the growth figures for individual countries as well. Several countries have shown especially dramatic growth in visitor exports over this time period. They have seen significantly increased inflow of tourism spending, thanks to prioritization of tourism, opening borders, infrastructure investment, and promotional efforts, among other factors (figure 1).

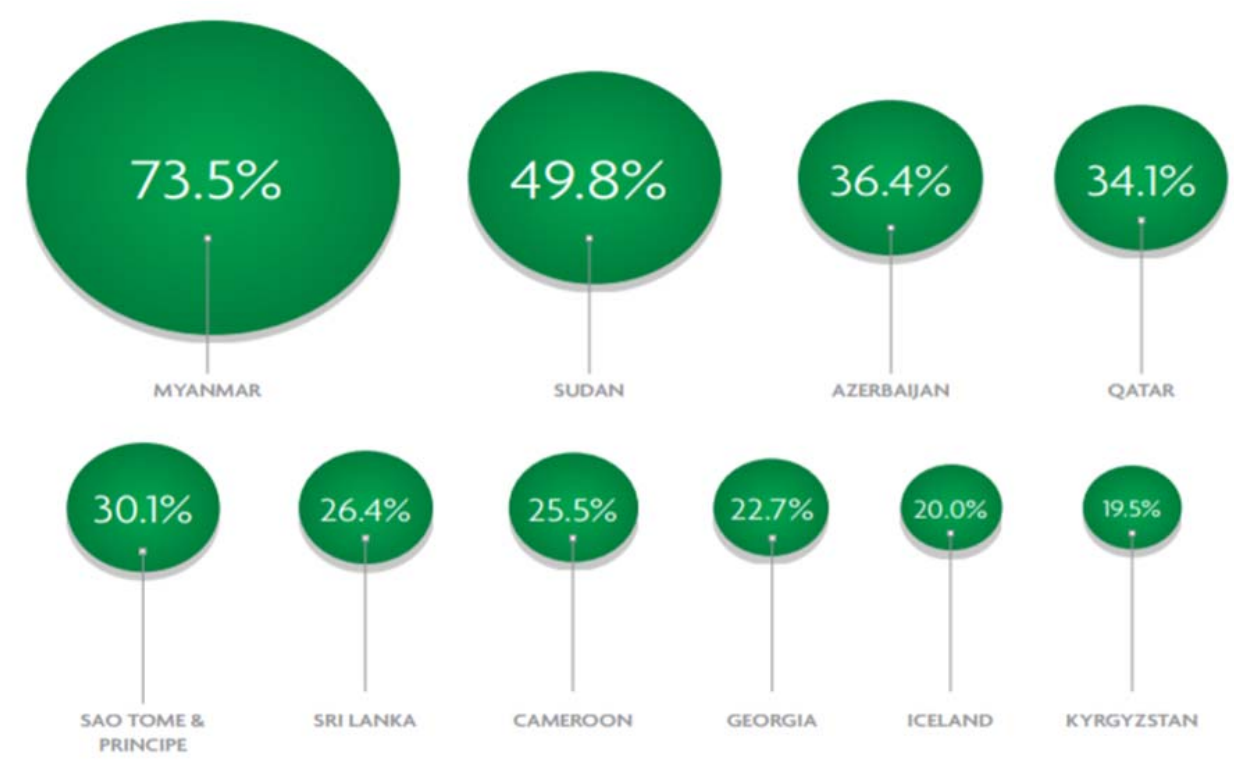

Figure 1. Visitor exports, (\%) (World Travel and Tourism Council: Travel \& Tourism Global Economic Impact \& Issues 2018 - March 2018)

Source: World Travel and Tourism Council: Travel andTourism Global Economic Impact and Issues 2018 - March 2018

Analysis of recent researches and publications. Globalization, as a major trend in the process of transformation of social development, has led not only to a global mega environment, but also to high competition for profitable markets, resources, investors and skilled labor.

W. Olins points out that there are three key paradigms of perception in consumption society: rational, emotional, symbolic, which the country cultivates as a key message to the outside world (W. Olins, 2012). According to sociologist J. Bodriard, symbolic exchange is becoming a fundamental universality (basic concept, attribute) of modern consumer society (M.Yu. Opyonkov, 2007). The above aspects are extremely important for the development of national tourism, since Ukraine as a territory has attractive tourist and recreational potential

A key factor for successful development and competitive advantage in a globalized world is a strong brand of territory. The formation of the brand of Ukraine as a tourist destination is a priority task of economic, social and cultural development of the territory, as it influences the attraction of foreign investments, strengthening of economic potential and integration ties. 
In this regard, let us present the position of researcher (J. Kunde, 2012) according to which, in a globalized economy, much of the well-being of countries is determined by their ability to export branded goods and services. This is due to the fact that a large part of the producers' profit comes from the value added by the brand (I. Staveren, 2001).

Responding to the challenges of globalization, the tourism brand, as a multilevel context of associative links with national tourism opportunities, interprets information in the direction of forming a set of emotional and rational ideas. They are the result of a comparison of country features (J. Kunde, 2012).

Nowadays the key factor of success and competitive advantage in the globalized world is becoming a national (regional) brand, as the most obvious and perceived characteristic on which the development of an export-oriented tourism model.

Review of previous studies and theoretical rationale. Studies of various aspects of territory branding have been reflected in publications and research. In particular, during the evolution of theory, three theoretical approaches (rational, emotional and social) were formed in the format of which the conceptual essence of the brand is evolving. Scientists such as Acker D. (1991, 1996, 2000),

Anholt, S. (2006), Barney, J. (1991), Kotler, P., Haider, D., \& Rein, I. (1993)., Blichfeldt, B.S. (2003), Hankinson, G. (2005), Morgan, N. J., Pritchard, A. and Piggott, R. (2003) have made a significant contribution to the study of brand formation.

Without reducing the importance of scientific developments in the process of branding at both macro and micro levels, it is important to emphasize that the urgent task is to create a brand of tourist destination aimed at promoting the process of promotion of national tourism products.

Presenting main material. The global imperative for the formation of a destination tourism brand is the need to successfully promote the national tourism product. Ukraine exports and imports tourism services, which creates a real precondition for forming a brand of territories in order to strengthen competitive positions in the growth of tourists, investments, strengthen integration ties and more. Therefore, it is important to create a brand of tourist destination, the concept of which is the dominant idea, built on the symbolization of values and resources of the territory. This approach is evidenced by the method of determining the most famous travel brands of countries by the international organization World Travel Market. The multifaceted focus on the brand of the tourist destination indicates that the basic foundations of its perception are laid at the macro level - equal strategic.

The scientific standpoint of understanding territory as a multi-purpose product that has many benefits for market agents is significant. In formalized perception, the usefulness of the territory for different agents (G. E. Kalinkina, 2012): 


$$
\sum_{i=1}^{n} P i=\sum_{i=1}^{n} \sum_{j=1}^{m} A i j Q j+\sum_{i=1}^{n} U i
$$

Where $P i$ - a set of benefits for external market agents;

$Q j-$ a set of benefits for internal market agents;

$A i j$ - the utility ratio of internal and external agents;

$U i-$ is an element that takes into account the impact of an institutional factor;

$n-$ is the number of external market agents;

$m-$ is the number of internal market agents.

Considering the above aspects is extremely important for the development of national tourism, since Ukraine as a territory has significant tourism and recreational potential.

Research of the tourist attractiveness of the countries according to the World Economic Forum has made it possible to see that the rating of this macro index, which summarizes 79 indicators of different vectors of development of the tourism sector, is conditioned by the availability of tourist resources, which are the primary criteria for attractiveness of tourist regions. This means that favorable geographical location, attractive tourist resources, availability of attractions, developed tourist infrastructure and skilled labor resources do not guarantee the successful development of tourism. In fact, a paradoxical situation arises when countries with less attractive natural and cultural and historical conditions than in Ukraine have a much higher rating of tourist attraction. To increase the rating of the tourist attraction of the destination, it is necessary to use geodifferentiation and positioning levers of the tourist space, which will reflect the distinctive features of the offer of the national tourist product.

In this regard, the formation of a brand of tourism in the global environment should be based on the following positions:

- first, the essence of the national tourism brand as the core of the development, positioning, promotion and perception of national tourism products; a mechanism for the economic growth of tourism in the regions to respond to the effects of the financial crisis, which has led to increased costs for outbound tourism; a megaproject characterized by information freedom and focused on long-term work in order to meet heterogeneous consumer demand and achieve tangible tangible results;

- second, the relevance of the formation of a national tourism brand, which is explained by the increased competition in the tourism market, which is accompanied by the transition from price competition to competition based on non-price competition. In such circumstances, a stronger position in a tourism enterprise that has a competitive brand (or brands) than one that has a strong position in the direction or market opportunities; the need for constant modification (differentiation) of tourism products; increasing the importance of networks of travel agents, which are wellknown and popular brands among consumers. 
Therefore, the global imperative for the brand of a tourist destination is the understanding that it: first, reflects the attractiveness of the tourist resources of the territories; second, has a strategic geo-economic orientation, as it focuses on the successful realization of national interests of tourism development. In this way, the brand of a tourist destination is an integrative and dynamic tool for reaping benefits and developing long-term relationships with target audiences based on emotional commitment and loyalty (A. Ben-Ner, L. Putterman, 2012).

- the rationale behind the global imperatives of brand a tourist destination allows us to conclude that the brand is a tool for protecting economic interests in tourism development. From these positions, we state the expediency of initiating the development of the National Tourism Development Program in order to:

- creation of export-oriented model of tourism development based on: identification of the most distinctive features for the formation of national tourism products (for example, on the basis of ethnic, religious, transit, ecological and other types of tourism), which reflect the world trends in perspective directions of the tourist offer;

- taking into account the regional specificity of tourism products, which will enable the specific region (territories) to specialize in the production and sale of tourist products due to the presence of distinctive consumer multiplicities of tourist resources of the territories, which are determined by the regional tourism specialization;

- development of measures to use the geopolitical position of Ukraine as a transit route for foreign tourists. It is recommended to step up the existing potential of interregional cooperation within the framework of organizational forms of managing cross-border cooperation (Euroregions, free economic zones, international transport corridors);

- reforming the information component of tourism services in order to raise awareness of foreign tourists about tourist potential, attract investors and potential foreign tourists;

- attraction of world-famous tourism brands to Ukraine to secure them in the tourist market, including on franchise terms;

- substantiation and formulation of national (regional) brand concepts for the development and promotion of national tourism products that determine the relevant effect of the brand (increase tourist flows, increase investment attractiveness and improve the social climate). The recommendation is to create a mechanism for integrating (information, financial, material) opportunities of all subjects of the tourist profile, especially in the regions for lobbying interests in tourism development;

- support for national heritage sites of socio-cultural, spiritual and historical value are of tourist interest and should form the basis of the distinctive features of a national tourism product. Recommendation is to create regional fundraising centers whose main function should be to search for financial, material and information 
resources for the preservation of historical and cultural heritage, to guarantee environmental safety;

- brand monitoring of changes in the international perception of tourist attractiveness on the basis of constant information and resource exchange.

Conclusion. Justifying the systematic nature of the imperatives of world tourism brands, it should be noted that this process should be regulated by state institutions and public organizations, which have the functions of developing the state's tourism policy and developing mechanisms for its implementation. Therefore, it is equally important to scientifically elaborate on these issues and develop practical recommendations, which will contribute not only to the revitalization of tourist flows, but also to enhancing the investment attractiveness of the tourism sector. This position is due to the fact that the brand of the tourist destination influences certain target audiences, is formed over a period of time and, accordingly, is the quintessence of national tourism policy, the success of which will have a significant long-term influence on the development of export-oriented tourism model.

\section{REFERENCES}

1. Weibing, ZHAO and Xingqun, L.I. (2007) Globalization of Tourism and Third World Tourism Development. A Political Economy Perspective, Retrieved from: http://egeoscien.neigae.ac.cn/fileup/PDF/20060303.pdf

2. McGrew, A. (1992). Conceptualizing Global Politics, Global Politics, pod red. A. McGrew, Polity Press. Cambridge, p. 28.

3. Risitano, Marcello (2005) The role of destination branding in the tourism stakeholders system. The Campi Flegrei case Retrieved from: https://pdfs.semanticscholar. org/0dd6/1cc2f599ddf8126ab527d5409b1246d830a6.pdf

4. World Travel and Tourism Council: Travel \& Tourism Global Economic Impact \& Issues 2018 - March 2018. All rights reserved. Retrieved from https:/www.wttc.org/-/media/files/reports/economic-impact-research/2018-documents/ global-economic-impact-and-issues-2018.pdf

5. Olins, W. (2012) How to Brand A Nation. London. 150 p.

6. Opyonkov, M.Yu. (2007) Kultura v ekonomike cennostej.Retrieved from: http://www.ifap.ru/pr/2007/n071217a.pdf

7. Kunde, J., Chatrchyan, S, Khachatryan, V., Sirunyan, AM, Tumasyan, A, Adam, W. (2012) Observation of a new boson at a mass of $125 \mathrm{GeV}$ with the CMS experiment at the LHCБ Physics Letters B 716 (1), 30-61

8. Aaker, D. (1991), Managing Brand Equity. Capitalizing on the Value of a brand names, The Free Press, New York.

9. Aaker, D. (1996), «Measuring brand equity across products and markets», California Management Review, $n^{\circ}$, spring, pp. 102-120. 
10. Aaker, D. Joachimsthaler, E. (2000) Brand Leadership: The Next Level of Brand Revolution, Handcover, New York.

11. Anholt, S. (2006). Public diplomacy and place branding: where's the link? Place Branding, 2(4), 271-275.

12. Barney, J. (1991), «Firm resources and sustained competitive advantage», Journal of Management, Vol. 17 (1), pp. 99-120

13. Blichfeldt, B.S. (2003), «Unmanageable Tourism destination Brands?», Working Paper Universityof Southern Denmark - Department of Enviromental and Business Economics, November.

14. Hankinson, G. (2005), «Destination brand images: a business tourism perspective», Journal of Service Marketing, Vol. 19, n ${ }^{\circ}$, pp. 24-32.

15. Morgan, N. J., Pritchard, A. and Piggott, R. (2003). Destination branding and the role of the stakeholders: The case of New Zealand. Journal of Vacation Marketing. 9(3): 285-299

16. Kotler, P., Haider, D., \& Rein, I. (1993). Maketing places: Attracting investment, industry and tourism to cities, states and nations. New York: Free Press.

17. Staveren, I. (2001) The Values of Economics - An Aristotelian Perspective. Irene van Staveren, Eburon Publishers. 242 p.

18. Kalinkina, G. E. (2012) Prostranstvenno-differencirovannye municipalnye mezosistemy i ih regulirovanie, Izhevsk, Izd-vo In-ta ekonomiki UrO RAN. 221 p.

19. Ben-Ner, A., Putterman, L. (2012) Economics, Values and Organization, Cambridge University Press. 557 p. 